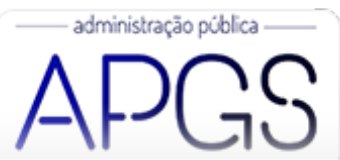

Administração Pública e Gestão Social ISSN: 2175-5787

apgs@ufv.br

Universidade Federal de Viçosa

Brasil

\title{
Análise do Controle Patrimonial de Bens Permanentes em uma Organização Pública
}

Carvalho Fernandes, Elizabeth; Auxiliadora Abranches Monteiro, Doraliza

Análise do Controle Patrimonial de Bens Permanentes em uma Organização Pública

Administração Pública e Gestão Social, vol. 11, núm. 4, 2019

Universidade Federal de Viçosa, Brasil

Disponível em: http://www.redalyc.org/articulo.oa?id=351560525009

Esta obra está bajo una Licencia Creative Commons Atribución-NoComercial-SinDerivar 3.0 Internacional. 


\title{
Análise do Controle Patrimonial de Bens Permanentes em uma Organização Pública
}

\author{
Analysis of Patrimonial Control of Permanent Assets in a Public Organization \\ Análisis del Control del Patrimonio de Bienes Permanentes en una Organización Pública
}

Elizabeth Carvalho Fernandes

Instituto Federal do Sertão Pernambucano, Brasil

Redalyc: http://www.redalyc.org/articulo.oa?

elizabeth.fernandes@ifsertao-pe.edu.br

Doraliza Auxiliadora Abranches Monteiro

Universidade Federal do Recôncavo da Babia, Brasil

doraliza.monteiro@ufrb.edu.br

id $=351560525009$

Recepção: 31 Janeiro 2019
Aprovação: 14 Agosto 2019
Publicado: 01 Outubro 2019

\section{Resumo:}

Este estudo objetiva analisar o controle de bens móveis de caráter permanente em um Instituto Federal brasileiro. Especificamente, buscou-se investigar como ocorrem as atividades relativas ao controle dos bens dentro de unidades gestoras da instituição, tais como o recebimento, a distribuição, a movimentação, os inventários e as baixas patrimoniais, e ainda apontar as dificuldades encontradas pelos servidores que executam as atividades dos setores de patrimônio. A abordagem metodológica foi qualitativa, do tipo exploratória e descritiva. Foi realizada a pesquisa documental nos registros patrimoniais, a aplicação de questionário a servidores dos setores de patrimônio e entrevistas semiestruturadas com os gestores e/ou responsáveis pela área de patrimônio de unidades gestoras da instituição. Os resultados demonstraram que não há padronização das atividades da área de patrimônio, que o controle patrimonial ocorre parcialmente e que não está sendo realizada a depreciação e a reavaliação dos ativos imobilizados. A estrutura organizacional precisa aproximar e fortalecer setores envolvidos no processo e adotar um sistema patrimonial realmente efetivo no controle dos bens móveis.

PalaVras-Chave: Gestão patrimonial, controle, bens permanentes.

\section{Abstract:}

The objective of this study was to analyze the control of permanent assets in the management units of a Brazilian Federal Institute of Education. Specifically, we sought to investigate how activities related to the control of assets occur within the management units of the Institution, such as the reception, the distribution, the moving, the inventories and the asset losses, including the identification of the difficulties found by the servers that perform the activities of the equity sectors. The methodological approach was qualitative, exploratory and descriptive. The documentary research was made in the patrimonial registries, the application of a questionnaire to servers of the patrimony sectors and semi-structured interviews with the managers and/or those responsible for the equity area of the institution's management units. The results showed that there is no standardization of the activities of the patrimony area, that equity control occurs partially and that the depreciation and revaluation of the fixed assets are not being carried out. The organizational structure needs to approximate and strengthen sectors involved in the process and adopt an effective asset system in the control of movable assets.

KEYWORDS: Patrimonial management, control, permanent assets.

\section{Resumen:}

Este estudio tiene como objetivo analizar el control de bienes muebles permanentes en un Instituto Federal de Educación de Brasil. Específicamente, trató de investigar cómo ocurren las actividades relacionadas con el control de los activos dentro de las unidades de gestión de la institución, como la recepción, distribución, movimiento, inventarios y amortizaciones de activos, y también señalar las dificultades encontradas por los servidores que realizan las actividades de los sectores de patrimonio. El enfoque metodológico fue cualitativo, exploratorio y descriptivo. Se realizó la investigación documental en los registros del patrimonio, la aplicación de un cuestionario a servidores en los sectores patrimoniales y entrevistas semiestructuradas con los gerentes y responsables del área patrimonial de las unidades de gestión de la institución. Los resultados muestran que no existe una normalización de las actividades del área patrimonial, que el control del patrimonio ocurre parcialmente y que la depreciación y la revaluación de los activos fijos 
no se están llevando a cabo. La estructura organizacional necesita acercarse y fortalecer los sectores involucrados en el proceso y adoptar un sistema patrimonial verdaderamente efectivo en el control de bienes muebles.

Palabras Clave: Gestión patrimonial, control, bienes permanentes.

\section{INTRODUÇÃo}

Este trabalho objetiva analisar o controle de bens móveis de uma organização da administração pública federal vinculado ao Ministério da Educação. A relevância da proposta se dá pela necessidade de investigar como é desenvolvida essa importante atividade para o uso eficiente de recursos e efetivo desempenho organizacional na oferta de serviços públicos.

A gestão patrimonial nas instituições públicas vem alcançando nas últimas décadas avanço significativo com a melhoria de procedimentos operacionais das atividades patrimoniais. Investimentos em tecnologias da informação e comunicação facilitaram as tarefas e a integração dos setores envolvidos no processo de controle. Adiciona-se a isso o aumento de capacitações para profissionais da área, além da necessidade de prestação de contas aos órgãos fiscalizadores, que evidenciou a importância do tema perante os dirigentes das organizações, como apontam Bernardes (2008) e Santos (2016).

No Brasil, o controle patrimonial tem vinculação com a contabilidade aplicada ao setor público alicerçada na Lei 4.320, de 17 de março de 1964, que estabeleceu regras que visavam a construção de administrações financeira e contábil, tendo como principal instrumento o orçamento público, produzindo consequências para os registros e demonstrações contábeis em que se sobressaíram os conceitos orçamentários em prejuízo à evidenciação dos aspectos patrimoniais.

Para atender à necessidade de convergência aos padrões internacionais de contabilidade pública e para que as informações contábeis sejam transparentes e comparáveis, além de compreendidas, independente de sua origem e localização, o governo brasileiro vem resgatando o real objeto da ciência contábil, o patrimônio. À medida que ocorrem essas mudanças, o controle patrimonial também ganha relevância dentro dos órgãos públicos.

Nesse sentindo, o presente estudo buscou analisar o controle patrimonial em um Instituto Federal de Educação, Ciência e Tecnologia brasileiro, a partir da percepção dos servidores da área de patrimônio, identificando como ocorre o fluxo de atividades dos bens móveis de caráter permanente, tais como recebimento, distribuição, manutenção e conservação, movimentação, inventário e baixa, bem como as dificuldades e falhas encontradas durante a execução das atividades de controle de bens móveis pelos servidores da área de patrimônio.

Embora haja pouca produção científica sobre o tema, destacam-se os estudos de Bernardes (2008; 2011), Cardozo (2013), Martins et al. (2013), Fenili (2015) e Santos (2002; 2016) sobre gestão e controle patrimonial em órgãos da Administração Pública. Destacam-se, especificamente, sobre gestão e controle patrimonial em Universidades, os estudos de Nascimento (2013) e Figueredo (2015), que revelam que a administração pública ainda não dispõe de sistemas de controle informatizado com características comuns que possa ser utilizado para atender às necessidades $\mathrm{da}$ área de patrimônio em diversos órgãos públicos. Santos (2016) ainda reforça que a gestão e o controle patrimonial nas organizações não obedecem à padronização e que a maioria dos órgãos públicos elabora manuais de procedimentos internos, tendo como base teorias relacionadas ao conteúdo e às legislações pertinentes ao tema que se enquadra em sua realidade, de modo a regularizar a situação patrimonial da instituição.

Deste modo, a questão norteadora do estudo é perceber, considerando as normas legais vigentes e o contexto administrativo de organizações públicas, como ocorrem as atividades de controle de bens permanentes no Instituto Federal do Sertão Pernambucano e quais as principais dificuldades para o controle efetivo? Em face das conjecturas teóricas e da práxis, partiu-se de pressupostos que o desenvolvimento do controle patrimonial nas unidades gestoras da organização pesquisada possuem: a) Ausência de padronização 
dos procedimentos e de normativas para execução das atividades da área de patrimônio; b) uso de dispositivos ineficientes de controle, de modo que a verificação do patrimônio não espelha a realidade; c) ausência de conformidade entre o controle físico e contábil dos bens.

\section{Aspectos teóricos SObre CONTROLE PATRIMONIAL EM ORgANIZAÇões PÚBLICAS}

A gestão patrimonial tem procedimentos administrativos básicos de aquisição, recebimento, guarda e distribuição semelhantes aos de outros materiais, diferindo apenas das atividades de movimentação e acompanhamento do uso dos bens patrimoniais, pois mesmo que os bens estejam sob a posse de seus usuários, devem ser monitorados e controlados até o fim de sua vida útil ou econômica.

Desse modo, para que o gerenciamento dos bens móveis pertencentes à instituição aconteça de forma adequada e eficiente, é necessário classificar e codificar todos eles, com o objetivo de simplificar, especificar e padronizar com numeração todos os bens da Instituição. Isso permitirá sua identificação e localização, além do seu histórico de entrada no acervo patrimonial da instituição através dos dados cadastrais do sistema de controle físico e contábil (Pozo, 2007).

Para a compreensão adequada dos preceitos da gestão e do controle patrimonial, faz-se necessário o conhecimento de determinados conceitos como carga, registro patrimonial, transferência, cessão, alienação e outros, que são apresentados no quadro abaixo. 


\section{Quadro 1 - Conceitos pertinentes à gestão e controle patrimonial.}

\begin{tabular}{|c|c|}
\hline CONCEITO & DESCRIÇ̃̃O \\
\hline Material & $\begin{array}{l}\text { Designação genérica de equipamentos, } \\
\text { componentes, sobressalentes, acessórios, veículos } \\
\text { em geral, matérias-primas e outros, empregados } \\
\text { ou passiveis de emprego nas atividades dos } \\
\text { órgãos e entidades públicas federais, } \\
\text { independente de qualquer fator. }\end{array}$ \\
\hline Carga & $\begin{array}{l}\text { É a efetiva responsabilidade pela guarda e uso de } \\
\text { material pelo seu consignatário. o bem será } \\
\text { considerado em carga quando efetivado o seu } \\
\text { registro no almoxarifado, após o cumprimento das } \\
\text { formalidades de recebimento e aceitaçăo. }\end{array}$ \\
\hline Descarga & $\begin{array}{l}\text { É a transferência da responsabilidade pela guarda } \\
\text { do material. Deverá ser baseada em processo } \\
\text { regular onde constem todos os detalhes do bem, } \\
\text { mediante uma das modalidades de movimentação } \\
\text { ejou desfazimento. }\end{array}$ \\
\hline $\begin{array}{l}\text { Registro } \\
\text { Patrimonial }\end{array}$ & $\begin{array}{l}\text { É a identificação atribuida a um bem dentro da } \\
\text { instituição. Corresponde a um código numérico } \\
\text { sequencial contendo as informações necessárias } \\
\text { para sua identificação, localização e carga } \\
\text { patrimonial. Também são chamados de tombo ou } \\
\text { tombamento. }\end{array}$ \\
\hline Responsável & $\begin{array}{l}\text { É aquele que assina o termo de responsabilidade } \\
\text { sobre o bem patrimonial. Geralmente é o chefe da } \\
\text { área em que o bem foi alocado ou a pessoa de } \\
\text { nivel hierárquico mais alto. }\end{array}$ \\
\hline Detentor & $\begin{array}{l}\text { É aquele que detém sob a sua guarda direta o bem } \\
\text { patrimonial. Os detentores dos bens patrimoniais } \\
\text { dentro das instituições serão responsáveis perante } \\
\text { as autoridades superiores. }\end{array}$ \\
\hline $\begin{array}{l}\text { Termo de } \\
\text { Responsabilidade }\end{array}$ & $\begin{array}{l}\text { É o documento através do qual se define a } \\
\text { responsabilidade pelos bens entregues aos } \\
\text { diversos setores iseus detentores. }\end{array}$ \\
\hline Transferência & $\begin{array}{l}\text { É a movimentação de material, com troca de } \\
\text { responsabilidade, de uma unidade organizacional } \\
\text { para outra, dentro do mesmo órgão. }\end{array}$ \\
\hline Cessão & $\begin{array}{l}\text { É a movimentação de material do acervo, com } \\
\text { transferência gratuita de posse e troca de } \\
\text { responsabilidade, entre órgãos ou entidades da } \\
\text { Administração Pública Federal direta, autárquica e } \\
\text { fundacional do Poder Executivo ou entre estes e } \\
\text { outros integrantes de quairquer dos demais } \\
\text { Poderes da União. }\end{array}$ \\
\hline Alienação & $\begin{array}{l}\text { Operação de transferência do direito de } \\
\text { propriedade do material, mediante a venda } \\
\text { (representada por processos licitatórios de leilão } \\
\text { com envio de propostas ou presencial, por } \\
\text { concorrência, por convite, ou processos } \\
\text { simplificados de venda quando os valores não são } \\
\text { muitos representativos e estão dentro do limite de } \\
\text { dispensa de licitação), permuta (representada pela } \\
\text { troca de um bem por outro, ou ainda como parte } \\
\text { de pagamento da aquisição de outro bem) ou } \\
\text { doaçâo (quando um bem é doado de uma } \\
\text { instituição para outra). }\end{array}$ \\
\hline $\begin{array}{l}\text { Inutilização ou } \\
\text { abandono }\end{array}$ & $\begin{array}{l}\text { São outras formas de renúncia ao direito de } \\
\text { propriedade do material (desfazimento), a } \\
\text { inutilização ou o abandono (relativo àqueles } \\
\text { materiais sem nenhum valor econômico) ocorrerá } \\
\text { quando verificada a impossibilidade ou a } \\
\text { inconveniência da alienação do material } \\
\text { classificado como irrecuperável, após a retirada } \\
\text { das partes economicamente aproveitáveis, } \\
\text { porventura existentes, que serão incorporados ao } \\
\text { patrimônio. A inutilizaçăo consiste na destruição } \\
\text { total ou parcial de material que ofereça ameaça } \\
\text { vital para pessoas, risco de prejuizo ecológico ou } \\
\text { inconvenientes de qualquer natureza para a } \\
\text { Administração Pública Federal. }\end{array}$ \\
\hline $\begin{array}{l}\text { Termo de } \\
\text { Transferência }\end{array}$ & $\begin{array}{l}\text { É o documento pelo qual é transferida a } \\
\text { responsabilidade por determinado bem de um } \\
\text { consignatário /organização para outro(a). }\end{array}$ \\
\hline Baixa & $\begin{array}{l}\text { Representa a saída, a eliminação ou a exclusão do } \\
\text { bem do acervo patrimonial da unidade, devendo } \\
\text { ocorrer de forma física e contábil, mediante a } \\
\text { autorização do dirigente da unidade gestora e } \\
\text { anuência da autoridade máxima da Instituição. }\end{array}$ \\
\hline
\end{tabular}


Elaborado pelos autores (2018) com base nos instrumentos legais e doutrinas que regulam a gestão e controle patrimonial.

Especificamente, a atividade de controle do patrimônio dos órgãos públicos deve satisfazer a três níveis básicos: Normativo, físico e contábil. Quanto ao aspecto normativo, deverá obedecer parâmetros e critérios estabelecidos pelas normas técnicas e legislação específica; quanto ao aspecto físico, deverão ocorrer as atividades de incorporação, uso e de baixa dos bens; e quanto ao aspecto contábil, deverá alimentar o sistema do ativo imobilizado com informações relativas aos saldos financeiros dos bens patrimoniais da instituição em tempo hábil (dentro do exercício) e ser transmitidas à contabilidade, considerando toda a movimentação dos bens físicos.

O presente estudo então, visa analisar o processo de controle dos bens móveis da instituição em relação aos aspectos normativos e à integração entre as áreas de patrimônio e contabilidade.

\subsection{Características e elementos do controle patrimonial}

De acordo com Santos (2002, p.11), “a administração patrimonial compreende uma sequência de atividades que tem o seu início na aquisição e termina quando o bem for retirado do patrimônio da instituição, e ao longo dessa trajetória são adotados inúmeros procedimentos físicos e contábeis" que determinam os dados históricos da vida útil de cada bem dentro da organização.

O controle patrimonial se inicia com a entrada do bem na carga patrimonial do órgão público e constitui atividade administrativa que visa a preservação e defesa do patrimônio da instituição, com a finalidade de acompanhar a posição física e financeira do ativo imobilizado de cada unidade administrativa. É voltado especialmente à verificação da localização, do estado de conservação, da utilização, dos prazos de garantia e manutenção.

É uma ferramenta de gestão importante, pois trata-se de um controle extracontábil, onde são registrados individualmente os bens e valores de cada unidade, além de ser uma exigência imposta pela Lei Federal 4.320/64 (Martins, 2012).

Em geral, as entradas dos bens móveis nos órgãos públicos, em sua maioria, acontecem através de compras realizadas de acordo com as previsões orçamentárias e limites de investimentos, que devem seguir os procedimentos de aquisição e contratação das diversas modalidades de licitação definidas em Lei.

Além da aquisição de bens, podem ocorrer outras formas de entradas na organização: Por produção própria de materiais, realizada através de processo regular, com base na apropriação de custos feita pela unidade produtora; por recebimento de bens originados de outras unidades do mesmo órgão ou de outras instituições, com base na movimentação de bens; e por modalidades de transferência, cessão ou alienação, conforme apresentado na figura abaixo.

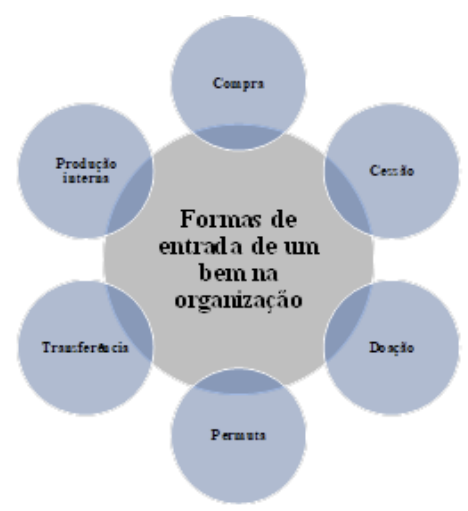

Figura 1 - Formas de entradas do bem na carga patrimonial em organizações públicas.

Fonte: Elaborada pelos autores (2018) a partir de Martins (2012). 
A partir do recebimento dos bens móveis na carga da instituição, estes deverão ser devidamente registrados no setor de controle patrimonial e essa ação irá possibilitar: a) $\mathrm{O}$ cadastramento do bem dentro do sistema patrimonial, b) a inclusão no ativo imobilizado (física e contabilmente), c) informações quanto a sua distribuição, d) localização do bem dentro da instituição, e) informações sobre o seu estado de conservação, e f) dados sobre garantia e manutenção periódica do referido bem (Santos, 2016).

Para saber a origem e acompanhar a movimentação física dos bens móveis dentro da instituição, o controle patrimonial requer a identificação do bem através da atribuição de um código sequencial, que deve ser providenciado pelo setor de patrimônio do órgão antes que este seja colocado para uso do setor ou servidor requisitante.

Segundo Pozo (2007), a classificação e a codificação dos bens dentro das suas características e finalidades é uma das atividades mais importantes da gestão patrimonial. A partir do registro patrimonial, cada bem adquirido terá um cadastro com as informações de todo o seu histórico, tais como: A data de aquisição, preço inicial, localização, vida útil esperada, valor depreciado, valor residual, manutenção realizada e previsão de substituição (Pozo, 2007).

Nesse sentido, Coutinho (2004) faz referência a dois dos deveres relacionados à gestão do patrimônio público, sendo eles: a) $\mathrm{O}$ dever de cadastramento, pois não é possível que o gestor público controle o que não conhece, assim, é necessário que mantenha organizados os arquivos com as informações de identificação e acompanhamento dos bens que estão sob a sua administração (relação com o Art.94 da Lei n 4.320/64), e b) o dever de promover o registro contábil, uma vez que a contabilidade permite, a partir do balanço patrimonial, demonstrar as variações patrimoniais aumentativas ou diminutivas sofridas pelo patrimônio inventariável da instituição, informações do que a administração realizou ou poderia ter realizado em termos financeiros, sendo este um mecanismo importante de controle interno para uso dos gestores públicos.

Ressalta-se a necessidade de avaliação do bem durante a sua vida útil e a inserção dessas informações junto ao setor de patrimônio e da Contabilidade relacionado ao Art. 89 da Lei no 4.320/64.

Em relação aos serviços contábeis a Lei no 4.320/64, estabelece no seu Art. 85 que

os serviços de contabilidade serão organizados de forma a permitirem o acompanhamento da execução orçamentária, o conhecimento da composição patrimonial, a determinação dos custos dos serviços industriais, o levantamento dos balanços gerais, a análise e a interpretação dos resultados econômicos e financeiros" (Brasil, 1964).

De acordo com Coutinho (2004, p.186), "para cumprir o seu papel, a contabilidade deve, pelo menos uma vez por ano, promover o inventário físico-financeiro dos bens móveis de caráter permanente e dos bens imóveis, de acordo com os registros analíticos feitos pelos Órgãos Gestores”. Ou seja, ao final de cada exercício financeiro é necessário que haja confrontação entre as informações oriundas do sistema de controle patrimonial quanto ao estado de conservação e valores de depreciação e reavaliação, em relação aos registros quantitativos e qualitativos escriturários de todos os bens móveis incluídos no sistema contábil da Instituição, para fins de validação das informações e para verificar o alinhamento entre esses dois sistemas de controle, pois deles depende o controle eficiente e eficaz do patrimônio da instituição.

Para auxiliar nessa tarefa, o gestor do patrimônio deverá emitir o Relatório Mensal de Bens (RMB), instrumento que reflete os valores financeiros dos bens móveis com as informações de entradas orçamentárias, extraorçamentárias, saídas, saldos anterior e atual, de acordo com o mês de referência, espelhando, assim, a situação do patrimônio da instituição com base no controle físico-contábil.

Sob esse aspecto, o Manual do Sistema Integrado de Administração Financeira do Governo Federal (SIAFI), em seu capítulo 020000, seção 021100, estabelece aos órgãos públicos federais a necessidade de acompanhamento mensal das movimentações de materiais nos almoxarifados e dos bens móveis da Unidade Gestora (UG), a ser realizado por suas unidades setoriais de contabilidade, conforme descrito a seguir:

2.2 - Após a emissão pela UG, os RMA [Relatórios de Movimentação de Almoxarifado] e RMB são encaminhados às Unidades Setoriais de Contabilidade em que a UG esteja jurisdicionada, até o $5^{\circ}$ (quinto) dia útil do mês subsequente ao de 
referência, juntamente com cópias dos seguintes Termos de Remanejamento: De cessão, de transferência e de doação, exceto para os órgãos que utilizam a conformidade documental descrita neste manual (STN/MANUAL SIAFI, 1996).

Em relação a esse ponto, obedecendo às novas normas contábeis, o Manual de Contabilidade Aplicada ao Setor Público (MCASP) orienta que a evidenciação dessas informações com o RMB deverá levar em consideração, para apurar o valor líquido contábil, as reavaliações, ajustes a valor recuperável, depreciação, amortização e exaustão.

As ações básicas que devem ser realizadas pela área de patrimônio durante a vida útil dos bens móveis para atender ao efetivo controle do patrimônio da instituição baseiam-se nas consideraçóes sequenciais ressaltadas por Martins (2012) e representadas na figura a seguir.

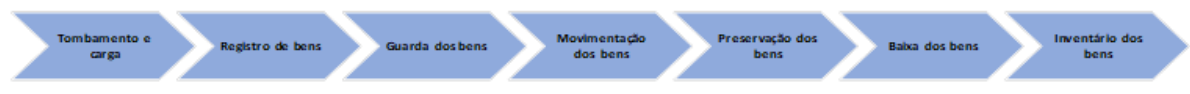

Figura 2 - Fluxo das atividades que compreendem o Controle Patrimonial Fonte: Elaborada pelos autores (2018) baseada em Martins (2012, p.6).

Segundo Quintana et al. (2011), o processo da gestão e controle dos bens públicos envolve fases distintas, descritas no quadro a seguir.

Quadro 2 - Fases do controle patrimonial em organizações públicas

\begin{tabular}{|l|l|}
\hline FASES & CARACTERÍsTICAS \\
\hline Recebimento & $\begin{array}{l}\text { O órgão recebe o bem do fornecedor e fica responsável por sua } \\
\text { guarda e conservação. }\end{array}$ \\
\hline Aceite & Recebimento definitivo e liquidação da despesa. \\
\hline Tombamento & $\begin{array}{l}\text { Identificação do bem através de um número sequencial, que, } \\
\text { quando possivel, é fixado no bem através de plaqueta ou } \\
\text { gravação. }\end{array}$ \\
\hline $\begin{array}{l}\text { Incorporação } \\
\text { (escrituração) }\end{array}$ & $\begin{array}{l}\text { Cadastro das informações essenciais dos bens (características } \\
\text { físicas, valor de aquisição, etc.) e tipo de entrada nos órgãos } \\
\text { públicos, que pode ocorrer por aquisição, doação recebida, } \\
\text { transferência, etc. }\end{array}$ \\
\hline Movimentação & $\begin{array}{l}\text { Deslocamento do bem dentro do âmbito de um órgão público, } \\
\text { que pode se dar através de requisição, devolução, } \\
\text { recolhimento, transferência, etc. }\end{array}$ \\
\hline $\begin{array}{l}\text { Desfazimento } \\
\text { (desincorporação, } \\
\text { baixa) }\end{array}$ & $\begin{array}{l}\text { É a retirada contábil de um bem do acervo patrimonial da } \\
\text { organização, que pode ocorrer por meio de cessão, alienação, } \\
\text { doação ou outras formas de desfazimento como: Extravio, } \\
\text { dano, obsolência ou desuso. }\end{array}$ \\
\hline
\end{tabular}

Fonte: Elaborado pelos autores com base em Quintana et al. (2011, p.129).

Com base nas fases acima referenciadas, em termos patrimoniais, após a aquisição dos bens móveis, o recebimento e aceitação pela instituição, o tombamento e incorporação ao sistema de controle e a distribuição ao setor ou usuário requisitante, estes ficarão sob a responsabilidade direta de algum setor específico ou servidor, até que ocorra a baixa física e contábil do acervo da instituição.

Durante o seu tempo de vida útil, os bens móveis serão acompanhados pelos seus responsáveis e pela área de patrimônio, que deverá fazer verificações rotineiras quanto a sua localização e o seu estado de conservação para melhor controle e preservação do patrimônio público. 


\subsection{Responsabilidades e controle sobre bens móveis}

Em relação ao acompanhamento e controle dos bens patrimoniais, o Decreto-Lei no 200/1967 determina que "os bens móveis, materiais e equipamentos de uso ficarão sob a responsabilidade dos chefes de serviço, procedendo-se periodicamente a verificação pelos competentes órgãos de controle” (Brasil, 1967).

Nos órgãos públicos de educação, os usuários dos bens são servidores técnico- administrativos, docentes, discentes, colaboradores e comunidade, que se beneficiam dos serviços e eventos promovidos pelas instituições. Em geral, a responsabilidade sobre esses bens é confiada aos coordenadores e chefes de setores, mesmo que estes sequer os utilizem, mas, por estarem no rol de responsáveis por parte do patrimônio, são cobrados por isso. Os demais usuários também estão sujeitos a sofrer as penalidades cabíveis no caso de danos ou desaparecimento de algum bem em que for comprovado o seu envolvimento.

A própria Constituição Federal no Art. 70, parágrafo único, estabelece que "prestará contas qualquer pessoa física ou entidade pública que utilize, arrecade, guarde, gerencie ou administre dinheiros, bens e valores públicos ou pelos quais a União responda, ou que em nome desta, assuma obrigações de natureza pecuniária" (Brasil, 1988).

Ao tomar conhecimento da utilização irregular do bem, o gestor público deve adotar as providências necessárias para sanar o problema e apurar a responsabilidade de quem é responsável por ele. Via de regra, a conservação do patrimônio já faz parte dos deveres do gestor, uma vez que, em razão da indisponibilidade do interesse público, ele não pode permitir que o bem deixe de cumprir a sua finalidade.

A Lei de Responsabilidade Fiscal (LRF) reforçou o cumprimento desse dever perante as despesas públicas, elevando-o à categoria de princípio, devendo inclusive ser objeto de planejamento do gestor público. Tal obrigatoriedade deve ser fiscalizada pelos órgãos de controle, pois a deterioração do bem provoca a redução do seu valor, com efeitos sobre o patrimônio líquido da instituição (Coutinho, 2004).

Dessa forma, os bens públicos pertencentes à União, estado, município, autarquia ou empresa pública requer do usuário ou detentor da sua responsabilidade os cuidados necessários ao seu uso, manutenção, conservação e, principalmente, guarda e zelo desses materiais. Qualquer ocorrência com relação à movimentação, dano, extravio (do bem ou de sua plaqueta de identificação) e alterações de suas características (retirada de partes) devem ser imediatamente informadas ao setor de patrimônio, que deverá manter cadastro atualizado com as informações relativas aos bens e emitir termos de responsabilidades aos seus usuários (Santos, 2002; Bernardes, 2008; 2011).

No termo de responsabilidade, documento pelo qual se define a responsabilidade pelos bens móveis entregues aos diversos setores e usuários (detentores), deverão constar informações cadastrais dos bens, identificação e assinatura do seu responsável, que deverá ser atualizado em caso de redistribuição dos bens e a cada mudança de consignatário.

Sobre as responsabilidades com o patrimônio, são feitas algumas pontuações estabelecidas pela Instrução Normativa SEDAP/PR nº 205 de 08 de abril de 1988, dispostas abaixo. 


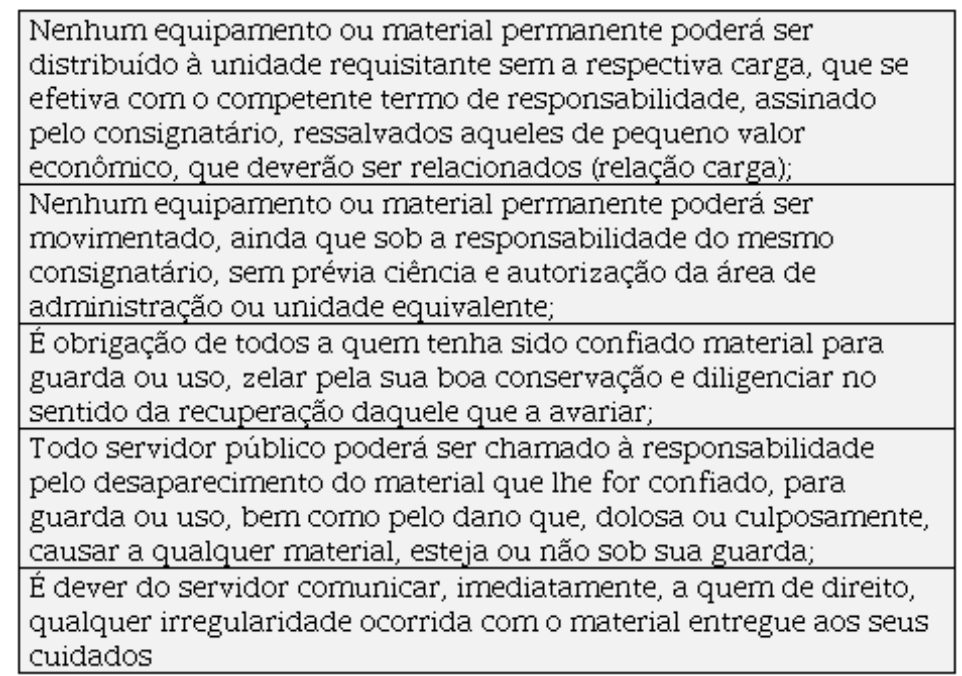

Desse modo, aqueles que causarem danos ao patrimônio público estarão sujeitos a responsabilização administrativa, civil e penal. As ações para a preservação e proteção dos bens públicos ficam por conta dos próprios órgãos da Administração Pública, bem como do Ministério Público, através de processos administrativos, ações de improbidade administrativa, ações penais e civis de ressarcimento dos prejuízos ao erário.

A defesa dos bens sob a guarda da instituição está inserida no dever de guarda, que também está relacionado aos princípios do controle e da fiscalização. Aliás, a guarda e vigilância do bem deve ser zelada conforme a destinação legal que lhe foi atribuída.

Conforme o Decreto $n^{\circ}$ 3.591/2000, o Sistema de Controle Interno do Poder Executivo Federal é composto pela Controladoria Geral da União (CGU) como órgão central e pelos órgãos setoriais responsáveis pelo controle interno dentro de cada órgão ou entidade (Brasil, 2000). Abaixo estão algumas das competências do controle interno, de acordo com o disposto no art. 74 da Constituição Federal, combinado com a Lei $\mathrm{n}^{\circ} 10.180$, de 06 de fevereiro de 2001, que organiza e disciplina a contabilidade federal e o controle interno do poder executivo federal.

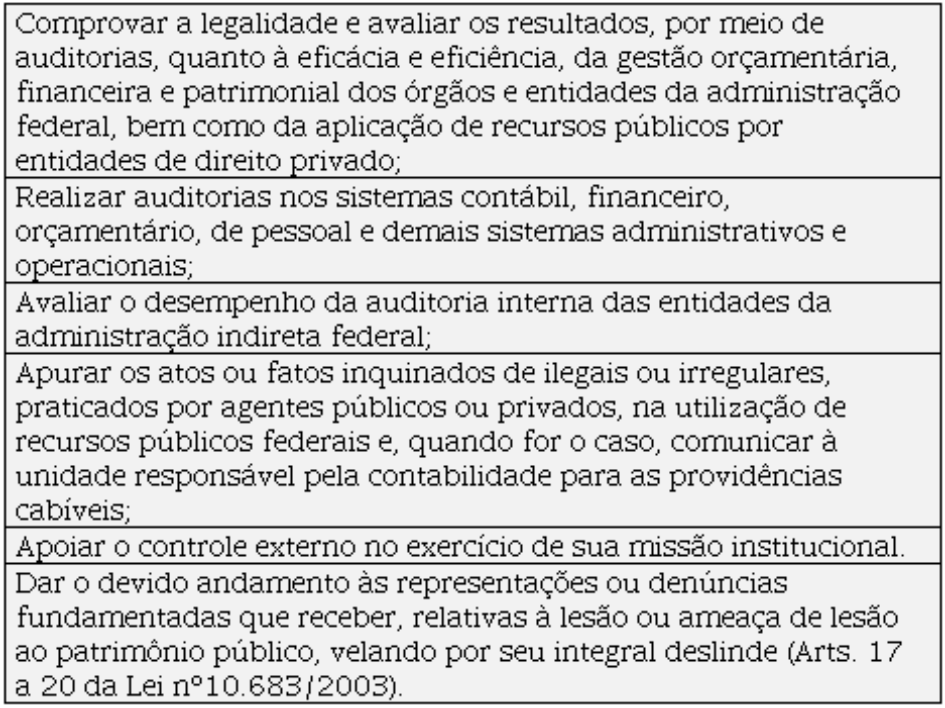


De acordo com Quintana et al. (2011, p.145), "o controle interno pode ser entendido como todas as ações e medidas adotadas numa entidade, destinadas a prevenir e salvaguardar o patrimônio daquela, bem como acompanhar os processos e rotinas ali existentes”. Compõe a estrutura organizacional da organização estudada o setor de Auditoria Interna, responsável por acompanhar e fiscalizar o controle interno da instituição. Sua função é orientar a gestão quanto às falhas que, porventura, sejam verificadas nos atos realizados pela Administração, agindo previamente à visita da CGU. Há de considerar também que o principal agente de controle externo responsável pelas normativas e fiscalização dos atos é o Tribunal de Contas da União (TCU).

\section{Procedimentos metodológicos}

A abordagem metodológica do estudo é qualitativa, do tipo exploratória e descritiva (Cervo, Bervian \& Silva, 2007). A coleta de dados ocorreu entre os meses de junho e dezembro de 2017. Constituíram como lócus de análise os setores de patrimônio das unidades gestoras (UG) localizadas em diferentes municípios, já que a organização educacional pesquisada, o Instituto Federal do Sertão Pernambucano (IF Sertão -PE) é multicampi, arranjo organizacional comum de universidades e institutos federais brasileiros.

Os instrumentos de coleta de dados foram roteiros de entrevista, questionário e documentos, fontes primárias e secundárias. Os sujeitos de pesquisa foram servidores responsáveis pela atividade de gestão patrimonial na instituição, contemplando chefes de departamento, coordenadores e agentes patrimoniais, servidores públicos lotados nas diversas unidades administrativas do IF Sertão-PE, capazes de analisar com mais profundidade o fenômeno analisado e a realidade organizacional sobre os aspectos de controle patrimonial.

A entrevista seguiu um roteiro semiestruturado dividido em três partes, contendo aspectos relacionados ao fluxo de atividades, caracterização dos inventários (não discutida neste artigo) e dificuldades apontadas no controle de bens pelos servidores.

Dentre os 7 servidores entrevistados, cinco são executores diretos do controle dos bens móveis das unidades (coordenadores e agentes), dois servidores ocupam a função de chefe de departamento, também chamados de gestores administrativos, aos quais estão subordinados os setores de patrimônio pesquisados.

Para manter o sigilo dos envolvidos e das unidades de pesquisa, os servidores não foram identificados, apenas chamados de "entrevistados" e enumerados em ordem temporal de aplicação das entrevistas, não importando o campus ao qual pertenciam.

O questionário versou sobre o processo de controle patrimonial em relação ao uso, zelo e a guarda dos bens móveis. Foi dividido em três blocos com questões que permitiram caracterizar o perfil pessoal e profissional dos responsáveis pela execução do controle dos bens móveis na unidade (não discutido neste artigo) e apreender a percepção dos servidores em relação à efetividade do controle dos bens móveis, além de aspectos organizacionais sobre o desempenho do controle patrimonial.

Tais unidades foram identificadas pelas letras A, B, C, D, E, F, G e H. Destas, três foram escolhidas para aplicação e análise de todos os instrumentos de coleta de dados (entrevista, questionário e documentos), por se localizarem em áreas geográficas próximas da unidade central, bem como pela representatividade institucional, relevância orçamentária e tempo semelhante de implantação. Nas outras unidades houve o envio do questionário semiestruturado pelo Google Forms, dirigido aos 10 coordenadores/servidores da área de patrimônio lotados em todas as unidades.

Portanto, a coleta de dados foi dividida em três etapas: Pesquisa em documentos oficiais como resoluções, instruções normativas, portarias e relatórios de gestão; aplicação de entrevistas a servidores (gestores, coordenadores e agentes); e, por último, aplicação do questionário para todas as unidades. 
O tratamento dos dados documentais e das questões de livre resposta da entrevista se deu pela análise de conteúdo. A análise de conteúdo foi feita por categorias temáticas vinculadas à gestão e ao controle de bens patrimoniais.

\section{Resultados e discussão}

\subsection{Fluxo de atividades de controle de bens permanentes no IF}

A gestão patrimonial dentro dos institutos federais obedece às rotinas necessárias ao registro de entrada, ao controle e à descarga dos bens móveis adquiridos. São constituídas por atividades ou procedimentos que ocorrem durante o período de vida útil desses bens. Nesta seção é exposto como tais atividades ocorrem na instituição analisada.

De acordo com a análise dos documentos institucionais e relatos na entrevista, não há padronização dos procedimentos componentes do fluxo das atividades da área de patrimônio. $\mathrm{O}$ próprio coordenador ou servidor competente lotado no setor de patrimônio é quem desenvolve estas tarefas de modo a garantir o fluxo mínimo estabelecido em lei. Foi constatada a inexistência de fluxograma, carta de serviços ou manual que defina as atividades da área de patrimônio de forma uniforme para toda a instituição. Mesmo nesse caso haveria de se levar em consideração as particularidades de cada unidade gestora, mas, sobretudo a estruturação formalizada desse processo traria homogeneidade aos procedimentos idênticos do controle patrimonial que ocorrem em suas unidades.

Para orientar a execução das atividades patrimoniais, os servidores da área de patrimônio contam atualmente com a Resolução no 18 do Conselho Superior da instituição, emitida e publicada em 14/06/2017. Ela aprova a Instrução Normativa (IN) cuja finalidade é disciplinar no âmbito do Instituto os procedimentos inerentes ao recebimento, aceitação, controle, padronização, distribuição, alienação, inventário, depreciação e baixa dos bens integrantes do seu patrimônio.

Foi identificado que desde a última portaria normativa emitida no ano de 2006 até a emissão e publicação da nova atualização em 2017, passaram-se aproximadamente onze anos até que a gestão concretizasse uma ação necessária à área de patrimônio como se constata no Relatório de Gestão: “[...] As atividades de guarda, estoque e inventário de bens e valores ainda estão regidas por norma antiga que deverá ser atualizada.” (2012, p.114).

Percebeu-se durante as entrevistas que há necessidade de que os servidores da área de patrimônio atualizemse com relação à adoção e aplicação das orientações da IN publicada em 2017, pois apenas os entrevistados E5 e E7 relataram conhecer a nova normativa, como exposto nas descrições a seguir.

Não há um fluxograma padrão para os setores de patrimônio, as orientações são seguidas e repassadas aos servidores no dia a dia das atividades da área. Mas já contamos com uma instrução normativa da Instituição aprovada este ano pelo CONSUP [Conselho Superior], com as orientações necessárias ao serviço (E5, entrevista, 2017).

[...] eu me baseio em uma norma interna do TCU, que é bem completa e atende [a] todos os requisitos com relação aos tramites do patrimônio. [...] As normativas do TCU que eu prefiro seguir, pois a da instituição eu olhei, mas não gostei, achei muito vago, ela não tem muitas especificidades, é algo até de senso comum (E7, entrevista, 2017).

O setor público dispõe de diversos instrumentos legais para aplicar ao controle patrimonial e o conhecimento desses dispositivos pela gestão e servidores da área é essencial para o desempenho do serviço, pois muitas das decisões a serem tomadas nas atividades do patrimônio necessitam de embasamento legal. Para que as instituições públicas possam realizar uma boa administração dos seus bens móveis e imóveis, os servidores devem se manter atualizados quanto aos procedimentos e fazer uso das normativas e legislação pertinentes ao tema, conforme indica Santos (2016). 
No quadro abaixo foram listados alguns destes dispositivos legais utilizados para o acompanhamento e controle dos bens móveis e imóveis dos entes públicos citados pelos entrevistados e detalhados pelos autores.

Quadro 3 - Principais orientações legais sobre gestão e controle patrimonial

\begin{tabular}{|c|c|}
\hline $\begin{array}{l}\text { INSTRUMENTO } \\
\text { LEGAL }\end{array}$ & FINALIDADE \\
\hline Lei $4.320 / 64$ & $\begin{array}{l}\text { Institui Normas Gerais de Direito } \\
\text { Financeiro para elaboração e controle dos } \\
\text { orçamentos e balanços da União, dos } \\
\text { estados, dos municipios e do Distrito } \\
\text { Federal. }\end{array}$ \\
\hline $\begin{array}{l}\text { Decreto-Lei } n^{\circ} \\
200 / 67\end{array}$ & $\begin{array}{l}\text { Dispôe sobre a organização da } \\
\text { Administraçâo Federal, estabelece } \\
\text { diretrizes para a Reforma Administrativa } \\
\text { e dá outras providências. }\end{array}$ \\
\hline $\begin{array}{l}\text { Instrução Normativa } \\
\text { SEDAP n } 205 \text {, de } \\
\text { 08/04/1988, } \\
\text { publicada no Diário } \\
\text { oficial da União } \\
\text { (DOU) de } \\
11 / 04 / 1988\end{array}$ & $\begin{array}{l}\text { Disciplina o uso de materiais com objetivo } \\
\text { de racionalizar com minimização de } \\
\text { custos o uso dos mesmos nas diversas } \\
\text { atividades no âmbito do Sistema de } \\
\text { Serviços Gerais (SISG) }\end{array}$ \\
\hline $\begin{array}{l}\text { Decreto } n^{\circ} 99.658 \text {, de } \\
30 / 10 / 1990\end{array}$ & $\begin{array}{l}\text { Regulamenta, no âmbito da } \\
\text { Administração Pública Federal, o } \\
\text { reaproveitamento, a movimentaçăo, a } \\
\text { alienação e outras formas de } \\
\text { desfazimento de material. }\end{array}$ \\
\hline $\begin{array}{l}\text { Lei } n^{\circ} 8.112 \text {, de } \\
11 / 12 / 1990\end{array}$ & $\begin{array}{l}\text { Dispõe sobre o regime jurídico dos } \\
\text { servidores públicos civis da União, das } \\
\text { autarquias e das fundaçốes públicas } \\
\text { federais. }\end{array}$ \\
\hline $\begin{array}{l}\text { Lei } n^{\circ} 8.666 \text {, de } \\
21 / 06 / 1993\end{array}$ & $\begin{array}{l}\text { Regulamenta o art. } 37 \text {, inciso XXI, da } \\
\text { Constituição Federal, institui normas para } \\
\text { licitaçốes e contratos da Administraçấo } \\
\text { Pública e dá outras providências. }\end{array}$ \\
\hline $\begin{array}{l}\text { Decreto } n^{\circ} 1.171 \text {, de } \\
22 / 06 / 1994\end{array}$ & $\begin{array}{l}\text { Aprova o Código de Ética Profissional do } \\
\text { Servidor Público Civil do Poder Executivo } \\
\text { Federal. }\end{array}$ \\
\hline $\begin{array}{l}\text { Decreto } n^{\circ} 6.087 \text {, de } \\
2007\end{array}$ & $\begin{array}{l}\text { Altera os artigos. 5o, } 15 \text { e } 21 \text { do Decreto } \\
\text { no } 99.658 \text {, de } 30 \text { de outubro de } 1990 \text {, } \\
\text { que regulamenta, no âmbito da } \\
\text { Administração Pública Federal, } \\
\text { o reaproveitamento, a movimentação, a } \\
\text { alienação e outras formas de } \\
\text { desfazimento de material, e dá outras } \\
\text { providências. }\end{array}$ \\
\hline $\begin{array}{l}\text { Instrução Normativa } \\
\text { CGU n } 04 \text {, de } \\
17 / 02 / 2009\end{array}$ & $\begin{array}{l}\text { Possibilita a utilização de Termo } \\
\text { Circunstanciado Administrativo (TCA) } \\
\text { para a apuração de extravio ou dano que } \\
\text { implique em prejuizo de pequeno valor. }\end{array}$ \\
\hline
\end{tabular}

Fonte: Resultados da pesquisa (2017).

De acordo com as informações dos entrevistados das unidades A, B e C, no Instituto a área de patrimônio de cada unidade adota sua própria forma de trabalho e segue um fluxo de atividades que é repassado empiricamente aos servidores que ingressam no setor. Os servidores adequam modelos de outros órgãos, criam seus próprios formulários e termos para os trâmites realizados no setor, como se pode constatar na fala do entrevistado E1 (2017).

[...] aqui no nosso campus nós mesmos que criamos uma padronização em relação à planilha e ao controle de bens e até repassamos para alguns campi, existe essa troca de informação entre os campi, mas não existe um padrão assim dentro da 
Instituição. No geral, cada campus do IF Sertão-PE cria o seu meio de trabalhar e o que melhor lhe servir. Para as solicitações ao setor de patrimônio nós temos formulários e termos [...], pegamos de outros modelos e adequamos à nossa necessidade, não é um padrão do IF Sertão-PE, pois não existe um manual do patrimônio, tipo um caderno, um manual do Instituto, não é um padrão que usamos, mas nós temos os termos e dá certo, com relação a isso é tranquilo, mas, se tivéssemos o sistema da instituição, tudo já estaria padronizado, não precisaríamos estar criando(sic) (E1, entrevista, 2017, grifo nosso).

Nesse sentido, os servidores entrevistados (E2 e E4) consideram que padronizar os procedimentos para todo o Instituto seria o ideal para o desempenho do fluxo das atividades da área de patrimônio, pois traria resultados melhores para o controle dos bens móveis, facilitando as movimentações de bens entre os campi e as adequações contábeis. Isso é algo que eles anseiam, como se observa nas manifestações de um dos chefes de departamento e de um dos servidores que executam diretamente as atividades patrimoniais.

As atividades de patrimônio no campus seguem a legislação, mas não segue a um padrão para a execução na instituição, o procedimento que é adotado aqui eu não sei se os outros campi adotam, mas a ideia é que realmente seja adotado um procedimento só, uma única instrução, uma coisa só (E2, entrevista, 2017).

Não temos uma padronização geral da Instituição, não temos manual e nem fluxograma próprio da Instituição para seguir, é só o procedimento interno mesmo, era bom que tivéssemos essa padronização, que sentasse o patrimônio junto com toda a Instituição e fizesse essa padronização única. [...] seria interessante que tivéssemos formulários específicos, um padrão não só para o nosso campus, mas também para todos os campi (E4, entrevista, 2017).

A falta de padronização nos procedimentos patrimoniais das instituições públicas é tema que já vem sendo discutido pela Administração Pública. Registrou-se essa preocupação em discussão nacional, realizada no segundo semestre do ano de 2001, com o apoio do Conselho Nacional de Secretários de Administração (CONSAD), sobre a situação atual dos estados da Federação e do Distrito Federal na área de gestão e controle patrimonial. Esta iniciativa resultou na elaboração de documentos que apontaram o diagnóstico sobre os principais obstáculos encontrados nessa área e elaboraram propostas concretas de ações necessárias à superação dessas dificuldades, como apresenta Coutinho (2004).

Considerando que o controle deve fazer parte das prioridades de gestão e tomada de decisão do gestor público, foi observada a necessidade de esforços conjuntos da gestão, dos servidores da área e dos usuários dos bens para garantir o controle efetivo.

Percebe-se que embora a instituição não siga uma padronização, formalizada mediante manual ou até mesmo um fluxograma que estabeleça os procedimentos internos adotados em cada UG, as unidades seguem os procedimentos do fluxo indicado na Figura 3. O desenvolvimento das atividades básicas do patrimônio vão desde a incorporação dos bens móveis em sua carga, acompanhamento e baixa, conforme as respostas dadas pelos coordenadores e servidores da área de patrimônio. 


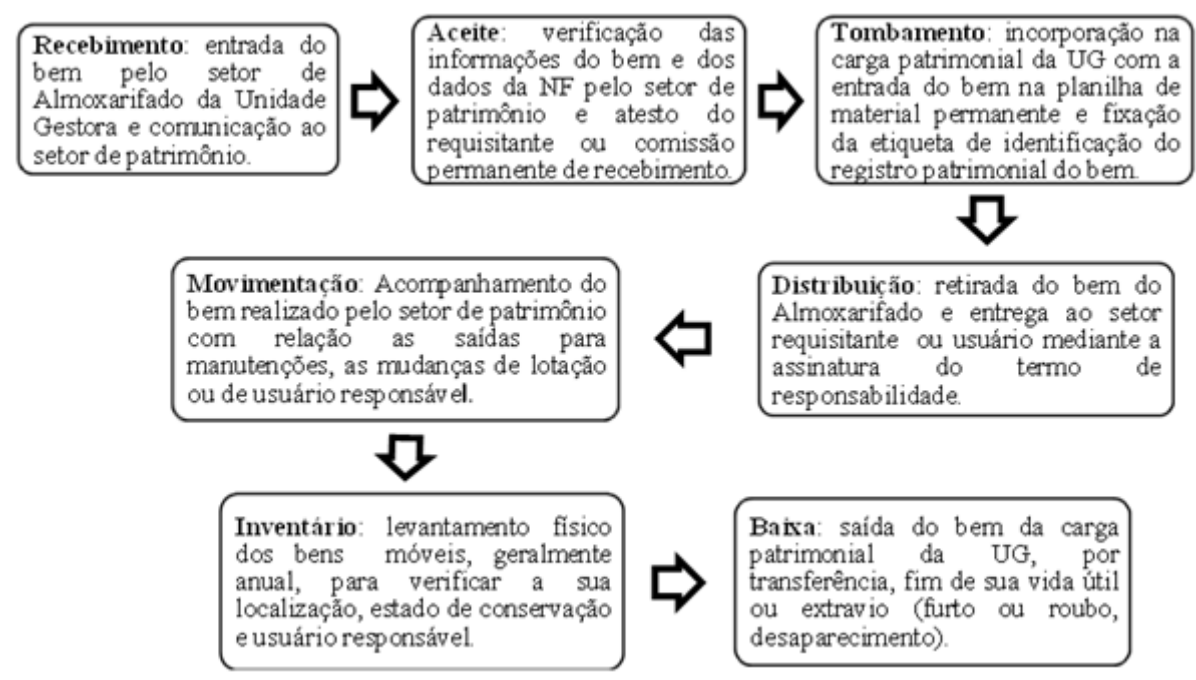

Figura 3 - Fluxo das atividades patrimoniais nas unidades gestoras do IF Sertão-PE Fonte: Elaboração feita pelos autores a partir das informações das entrevistas (2017).

Como destaca Santos (2016), a gestão patrimonial deve ser baseada em normas e procedimentos que definam as rotinas de aquisição, entrada, registro, identificação e responsabilidade pela carga de bens, a fim de proporcionar a realização de um eficiente acompanhamento dos bens integrantes do ativo imobilizado. É fundamental que todos os envolvidos no processo de controle patrimonial estejam conscientes da sua importância para o sucesso da organização.

Entretanto, em relação ao cumprimento dessas etapas, o coordenador de patrimônio da unidade B revelou que muitas vezes o bem chega ao almoxarifado e é retirado pelo requisitante sem o conhecimento do setor de patrimônio, gerando problemas ao controle dos bens, uma vez que o material deixa de ser incluído na planilha de entrada de bens, de ser tombado e de ser entregue ao setor ou usuário requisitante mediante a assinatura do termo de responsabilidade sobre a devida guarda daquele bem.

Ainda segundo ele, quando o setor de patrimônio toma conhecimento de um fato desses, é que sai à busca de localizar a nota fiscal de venda e o próprio bem, para então realizar os procedimentos das atividades patrimoniais que fazem parte do processo de controle de patrimônio. A ausência desses procedimentos prejudica a eficiência do controle patrimonial, como exposto no comentário do entrevistado E7.

Eu acredito que o controle patrimonial não está melhor porque o pessoal não respeita os trâmites da área de patrimônio, principalmente quando os bens chegam ao almoxarifado, e depois quando os responsáveis já estão de posse dos bens, [...] movimentam os bens e não avisam ao setor de patrimônio (E7, entrevista, 2017).

Diante dessa constatação, verifica-se a necessidade de aproximação das partes envolvidas no processo de controle, bem como a importância de que sejam seguidas as normas e procedimentos relativos ao gerenciamento dos bens móveis.

\subsection{Dificuldades encontradas na instituição e melhorias propostas}

A falta de organização e padronização do sistema de controle patrimonial nos órgãos públicos é um dos fatores geradores das dificuldades em pôr em prática as regras e as orientações do Plano de Contas Aplicado ao Setor Público (PCASP), e, consequentemente, para orientar as Demonstrações Contábeis Aplicadas ao Setor Público (DCASP). A observância a tais procedimentos é obrigatória e estes são posteriormente fiscalizados pelos órgãos de controle interno e externo, como a CGU e o TCU. 
Entre tais procedimentos contábeis, tem-se a depreciação e reavaliação dos bens móveis e imóveis do seu patrimônio. Entretanto, em geral, os órgãos do governo têm encontrado dificuldades para obedecer a essa determinação dentro dos prazos estabelecidos, inclusive já revistos pela Portaria STN no 548 , de 24 de setembro de 2015.

Ao longo desses quase nove anos, a maioria dos órgãos públicos ainda não realizou a depreciação aplicada à vida útil dos bens da sua carga patrimonial, bem como não procedeu à reavaliação dos valores de seus bens móveis e imóveis, cuja realização é de caráter obrigatório e deve ocorrer em períodos de quatro em quatro anos. O coordenador $\mathrm{E} 5$ revela que a depreciação dos bens vem sendo realizada parcialmente pela unidade C:

A unidade C está fazendo esta depreciação em uma parte dos bens através do SIGA ADM [Sistema Integrado de Gestão Acadêmica], pois nem todas as informações que foram lançadas no banco de dados do sistema estão de acordo com as classificações das aquisições, nem todas as informações técnicas estão fiéis, por exemplo, às vezes encontramos distorções nas notas fiscais da compra de determinado equipamento (E5, Entrevista, 2017).

Na pesquisa documental dos relatórios de gestão de 2012 a 2016, observou-se que o Instituto não realiza a depreciação dos bens móveis na maioria das suas unidades gestoras, caracterizando um ponto falho do seu sistema de controle interno e patrimonial, assim como se verifica no comentário do entrevistado a seguir.

Para lhe ser bem sincero, eu não sei nem como é feito esse procedimento aqui na instituição, pois não temos proximidade com o setor contábil com relação a esse tema, não sei como a depreciação dos bens está sendo realizada na instituição, eu presumo que seja feita pela [área de] Contabilidade, mas não sei dizer a forma como está sendo feita [...] (E1, Entrevista, 2017).

Constatou-se que o sistema de controle patrimonial da instituição não está unificado para as unidades e que carece avançar nesse sentido. As modificações ocorridas nas normas aplicadas à Contabilidade Pública Brasileira por conta das exigências de adequação aos padrões internacionais, tirou do controle o foco exclusivo sobre o orçamento público e colocou em evidência os aspectos patrimoniais. Dessa forma, a alta gestão deve buscar alinhar o trabalho desempenhado na área de patrimônio como o da contabilidade de sua unidade gestora, uma vez que os bens móveis devem ser geridos sob os três aspectos: Normativo, físico e contábil. Um dos gestores entrevistados já demonstra em seu relato essa preocupação, conforme se percebe a seguir.

Para o atendimento das normas técnicas, estamos procurando estreitar os laços com a Contabilidade do campus, já fizemos uma proposta de trabalho para que conjuntamente possamos sanar os problemas do patrimônio [...], mas a gente percebe que em outras unidades ocorre também esse distanciamento, a contabilidade se resume mais às despesas contábeis, financeiras, custeios do exercício, o patrimônio ainda não está em destaque, mas existe o interesse por parte da contabilidade local em ajustar isso (E6, Entrevista, 2017).

Ainda na opinião do entrevistado E6, o fato de a instituição não ter funcionando um sistema patrimonial que atenda as necessidades exigidas pelas NCASP atesta a inexistência do seu controle patrimonial perante os órgãos de controle interno e externo e é algo que a gestão precisa corrigir no âmbito institucional.

O sistema de controle na verdade não existe, foi feito um paliativo para atender um controle em nível de campus, agora, a nível gerencial dos órgãos de controle a gente não tem esse acompanhamento efetivo, porque hoje trabalhamos com a alimentação de uma planilha de Excel, tudo que entra e sai é movimentado nessa planilha, com a mudança do plano de contas e outras alterações da lei, o programa, o sistema que temos se tornou obsoleto, então não existe (E6, Entrevista, 2017).

Duas das unidades gestoras (A e B) têm carga patrimonial bastante significativa, e para atender ao desenvolvimento das atividades patrimoniais, fazem uso de sistema de planilhas do programa Microsoft Excel utilizadas para o controle dos bens móveis que são alimentadas manualmente sem o auxílio de qualquer tipo de dispositivo facilitador da coleta de dados.

Entretanto, a unidade $\mathrm{C}$, atualmente, além das planilhas do Excel utiliza também o módulo de patrimônio do Sistema Integrado de Gestão Acadêmica (SIGA-ADM), sistema disponibilizado pelo Ministério da Educação (MEC) para utilização da área de Administração dos institutos federais para o acompanhamento de serviços como protocolo, almoxarifado, patrimônio e transportes. 
No entanto, os coordenadores e servidores das unidades A, B e C demonstraram-se insatisfeitos com a ferramenta de controle do patrimônio e acrescentam que o sistema não traz a segurança desejada à fidelidade dos dados imprescindíveis ao acompanhamento e gerenciamento dos bens, como se observa nos relatos a seguir.

Eu considero que o trabalho de controle do campus é precário, porque ainda trabalhamos com base em planilhas de Excel [...]. O nosso sistema de controle satisfaz em parte [...], se fosse um sistema informatizado, que até pelo fato de ser mais seguro seria bem melhor, se fosse pra dar uma nota de 0 a 10, eu daria uma nota seis (E1, Entrevista, 2017).

O sistema de controle utilizado não satisfaz, é péssimo! É péssimo porque ele não proporciona segurança para os dados quando o usuário está manipulando o banco de dados, é uma planilha [do programa] Excel, então mesmo que você bloqueie a planilha, podem ocorrer ameaças, porque é um bloqueio frágil, uma vez que qualquer modificação que [se] precise realizar, você tem que desbloqueá-la, eu já encontrei várias falhas na planilha e alterações que eu digitei. É péssimo (E7, Entrevista, 2017).

Por outro lado, o entrevistado da unidade C, que utiliza o sistema patrimonial SIGA-ADM, assinala como ponto positivo na sua utilização o fato de o sistema permitir a movimentação de um bem entre unidades distintas, em tempo real e de forma on line. Além de possibilitar o cálculo dos valores de depreciações dos bens durante sua vida útil, atendendo o exigido pelas Resoluções SIAFI (Macrofunção 02.03.30), que trata das modificações e atualizações ocorridas na Contabilidade Pública aplicada ao ativo imobilizado da Instituição. Como pontos negativos, destaca-se que o sistema não reconhece as unidades gestoras separadamente, tudo é registrado em um único CNPJ, e a sequência de registros de patrimônio (tombamento) é única para toda a instituição, ou seja, o sistema não separa os RP de cada unidade, o que dificulta o trabalho de acompanhamento dos bens.

De acordo com os servidores entrevistados das unidades A, B e C, os setores de patrimônio não estão emitindo o Relatório Mensal de Bens (RMB), o que significa dizer que a conformidade físico-contábil do acompanhamento do controle do patrimônio da instituição não está sendo realizada.

Os servidores destacam a distância entre o contador e a área de patrimônio como um dos fatores que dificulta essa atividade, além da ausência de uso de sistema informatizado para o controle patrimonial, impossibilitando cálculos manuais ou com planilhas de Excel para cargas de mais de dez mil itens, por exemplo. Adiciona-se ainda a tendência de aumento, observada nos últimos anos, de investimentos em novos bens para suprir as demandas das áreas administrativas e acadêmicas da instituição.

Em geral, para a realização das novas aquisições, o setor de patrimônio não é consultado sobre a disponibilidade de bens, sobre as classificações desses materiais, ou mesmo se há algum registro de ocorrências com determinados bens já adquiridos anteriormente, inviabilizanodo novas compras. A respeito disso, um dos agentes patrimoniais comenta "[...] nem sempre sabemos o que o setor de compras está adquirindo, pode ser, inclusive, materiais que não tenha a qualidade necessária, e nem seja o que estamos precisando" (E3, 2017).

Revela-se, nesse sentido, outro ponto a ser pensado pela gestão em relação à organização das atividades administrativas dos setores de compras e patrimônio, que é a aproximação dessas áreas, que também contribuiria para o aprimoramento do controle patri monial.

É importante que haja troca de informações referentes aos bens que integrarão a carga da unidade, desde o planejamento para a sua aquisição até o seu recebimento e aceitação. Elas ajudam, inclusive, ao setor de patrimônio antever a sua programação com relação à execução das tarefas de recebimento, verificação do solicitante e aceite, tombamento, elaboração de termos de responsabilidade e distribuição do bem dentro da instituição.

Outro ponto importante para o controle interno é que o setor ou servidor requisitante dos bens que são adquiridos pelo setor de compras informem a especificação do material de forma adequada aos registros contábeis orçamentários e patrimoniais. $\mathrm{O}$ cadastramento indevido das classificações desses bens pode gerar 
erros para os sistemas de controle contábil e patrimonial. Essa foi uma das inconsistências apontadas pelo Órgão de Controle Interno (OCI) em uma das fiscalizações realizadas (RG, 2013, p.214).

No tocante à distribuição dos bens requisitados pelos servidores e à responsabilidade sobre a carga desses bens, um dos chefes de departamento afirma que o bem só é "colocado sob a guarda do servidor requerente, mediante a assinatura do termo de responsabilidade, não há dificuldades para as assinaturas dos termos, ou se faz desse jeito ou o bem, sem a carga patrimonial, não sai do departamento" (E2, 2017).

O coordenador E4 confirma o posicionamento de que o "bem é entregue com o responsável identificado" e continua dizendo que "os termos de responsabilidade sob os bens móveis distribuídos aos usuários, estão sempre sendo atualizados pelo setor, da melhor forma possível, mas a falta da ferramenta de controle também dificulta a atualização dos termos no dia a dia" (E4, 2017).

O outro chefe de departamento, E6, esclarece ainda que a resistência à assinatura dos termos por parte de algum usuário que possa ter ocorrido devido ao desconhecimento das normas patrimoniais, já foi superada, como se observa no relato a seguir.

A relação entre o setor de patrimônio e usuários está consensual, não há mais oposição quanto às assinaturas dos termos de responsabilidade, pois o recebimento dos bens está condicionado à assinatura dos termos. Então, a relação está de interesse, eu assino porque quero o bem, atualmente está amigável. Esta conscientização dos usuários passou a existir com a aplicação da legislação, então cada um é detentor da responsabilidade pelo bem que está recebendo, por sua guarda e por sua conservação (E6, Entrevista, 2017).

A falta de comprometimento dos detentores/usuários com a responsabilidade sobre os bens sob sua carga, deixando de assinar os termos e/ou atualizá-los por ocasião das verificações da equipe de patrimônio, podem ocasionar a não localização desses bens e causar falhas ao sistema patrimonial e controle interno da instituição (RG, 2012, p.128).

O gestor E6 ainda avalia que a comunicação entre os usuários e o setor de patrimônio quanto às movimentações de bens melhorou bastante: "Em termos percentuais digamos que estão em 90\%, digamos que $10 \%$ estão em fase de conscientização, mas se ajustando, são muitas vezes novos servidores que não tinham essa experiência de serviço público [...]” (E6, 2017).

Ocorrer essa comunicação é essencial para o bom desempenho do acompanhamento dos bens móveis dentro da instituição, tanto para atualização da localização e dos responsáveis (termos de responsabilidade) quanto para o seu recolhimento no momento em que o bem não esteja mais atendendo a sua finalidade, seja por ter sofrido danos ou por ter se tornado obsoleto, ou que o bem esteja em desuso no local de lotação, seja por ter se tornado desnecessário ou excedente.

Por outro lado, vários outros servidores citaram a movimentação indevida dos bens. Um dos agentes acredita que até no próprio setor a comunicação entre os servidores tem que ser melhorada, a fim de evitar registros indevidos da não localização de bens.

Geralmente, sistemas informatizados apresentam banco de dados cadastrais que permitem inserir informações diversas a respeito de cada bem da carga patrimonial da organização. Assim, as ocorrências registradas para aquele bem podem ser consultadas para a verificação da sua situação dentro da unidade, o que não se tem disponível com o atual sistema simplificado com registros por planilhas de Excel utilizado pelo Instituto.

No tocante à atividade de recolhimento dos bens, é comum que os setores de patrimônio dos órgãos públicos não tenham depósitos ou um local específico para a guarda dos bens que são retirados de uso.

Sob esse aspecto, os coordenadores de patrimônio responderam que, em geral, as unidades gestoras não têm depósitos específicos para acomodar os bens que chegam à instituição enquanto aguardam ser distribuídos, nem para aqueles recolhidos e que serão destinados a outros locais ou terão baixa da carga patrimonial. Em duas unidades a equipe de patrimônio sequer dispóe de sala própria para o funcionamento do setor, ocupando um espaço mínimo com uma mesa de trabalho e alguns armários, em um ambiente que é divido com outros setores do departamento de administração. 
Sob esse aspecto, Santos (2016) comenta que, apesar da importância da atividade patrimonial para as organizações, em muitas delas, o setor não possui uma área específica para o desenvolvimento de suas tarefas e seu funcionamento. Às vezes porque a gestão acredita que o movimento do serviço é pequeno ou porque acham que o responsável do almoxarifado pode acumular mais essa função.

A falta da estrutura física e de boas condições de trabalho para o desempenho dos serviços da área de patrimônio são fatores que dificultam a execução das atividades patrimoniais, como também desmotiva o servidor da área de patrimônio. Como se percebe no comentário do Coordenador E7, “[...] atualmente, muitas vezes estou de fone de ouvido para tentar me concentrar em alguma atividade, pois a sala é compartilhada, muitas vezes saio da sala para outra, para tentar elaborar algum documento" (E7, 2017).

Com base no relato dos chefes de departamento, coordenadores e agentes da área de patrimônio, foi elaborado o Quadro 4 com as dificuldades e soluções para o desempenho do controle patrimonial da instituição. 


\section{Quadro 4 - Dificuldades versus soluções para melhorar o controle patrimonial}

\begin{tabular}{|c|c|}
\hline $\begin{array}{l}\text { DIFICULDADES PARA O } \\
\text { CONTROLE PATRIMONIAL }\end{array}$ & $\begin{array}{l}\text { SOLUÇÕES PARA MELHORIA DO } \\
\text { CONTROLE PATRIMONIAL } \\
\end{array}$ \\
\hline 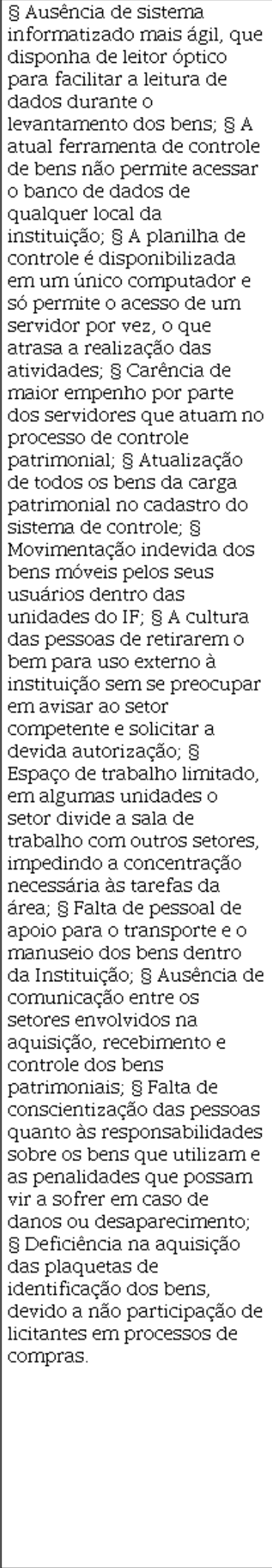 & 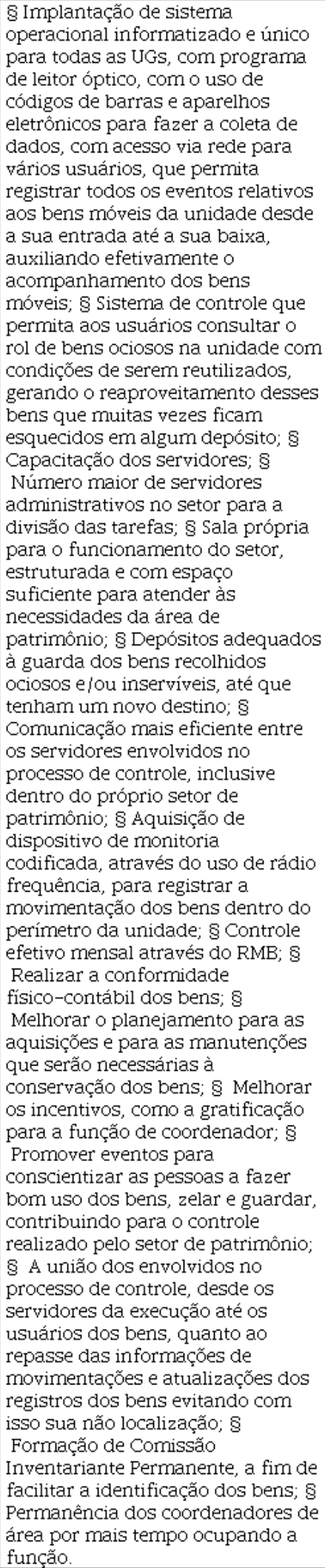 \\
\hline
\end{tabular}


Fonte: Dados da pesquisa (Entrevistas, 2017).

Percebe-se que as dificuldades que afetam o controle patrimonial e as soluções apontadas para a melhoria do seu desempenho resumem-se na execução conjunta de ações concretas por parte dos sujeitos organizacionais (gestão superior, coordenadores e servidores da área de patrimônio e os detentores e/ou usuários dos bens móveis), além de incentivos organizacionais, como condições de trabalho e espaço físico adequado.

Portanto, para superar as dificuldades do controle dos bens móveis permanentes e atender a padronização exigida pelas novas regras da contabilidade brasileira, é necessário observar os aspectos patrimoniais do controle físico e dos registros contábeis dos bens, bem como reunir esforços de todos os atores sociais envolvidos, além da adoção de ferramenta eficiente que torne o processo de controle patrimonial mais efetivo na instituição.

\section{CONSIDERAÇões FINAIS}

Este estudo buscou analisar, com base na percepção dos servidores da área de patrimônio em uma organização pública e de documentos institucionais, como está sendo realizado o controle bens móveis de caráter permanente e as dificuldades enfrentadas pelos servidores de patrimônio na execução das atividades de controle dos bens.

Constatou-se que o instituto federal analisado não faz uso de um manual de procedimentos para o desempenho das atividades da área de patrimônio, mas as suas unidades seguem ritos internos para o fluxo das tarefas que atendem satisfatoriamente aos servidores da área de acordo com o que a legislação recomenda.

Em relação à ferramenta de controle patrimonial, constatou-se que o sistema utilizado para o controle dos bens nas unidades não é único, pois existe o uso do sistema patrimonial SIGA-ADM e do sistema a base de planilhas do Excel, este último atende parcialmente às necessidades da área de patrimônio.

Desta maneira, a instituição está realizando a depreciação dos bens de forma parcial, pois existem unidades gestoras que não estão praticando a reavaliação dos bens permanentes e emitindo os Relatórios Mensais de Bens (RMB), conforme as exigências da NBCASP.

Por conseguinte, considerando que administração dos bens deve ser regida obedecendo a um conjunto de normas e princípios, o descumprimento das recomendações da legislação traz implicações à gestão, que poderá vir a ser penalizada com o pagamento de multas e com a responsabilização dos gestores públicos e servidores da área.

Assim, é indiscutível a necessidade da articulação entre as áreas de patrimônio, contabilidade e tecnologia da informação, alinhadas às diretrizes da alta administração das unidades gestoras e usuários dos bens, para que o controle melhore o desempenho e corresponda aos padrões exigidos pela legislação, além das exigências dos órgãos de fiscalização (interna e externa).

No que diz respeito à gestão, existe a necessidade de disponibilizar ferramenta eficiente para o uso efetivo de sistema patrimonial informatizado, com as características indicadas pelos servidores da área e que atenda às exigências indispensáveis ao controle físico dos bens e aos registros contábeis; estruturar os setores de patrimônio e o espaço de trabalho; melhorar a comunicação entre os setores envolvidos com o processo de controle, como os de compras e contabilidade, aproximando-os da área de patrimônio; melhorar os incentivos para os coordenadores de patrimônio, considerando a sua participação no rol de responsáveis da instituição, e promover eventos educativos com o objetivo de conscientizar os detentores da responsabilidade e/ou usuários dos bens.

Espera-se que este estudo contribua para a discussão sobre o controle patrimonial em organizações públicas visando o aperfeiçoamento desta função e que promova o uso efetivo e eficiente de recursos de modo a possibilitar o melhor aproveitamento dos bens adquiridos, redução de desperdícios e o reforço de boas práticas administrativas para o aperfeiçoamento da prestação de serviço público. Além disso, este estudo 
contribui para reflexão teórica e prática do campo de estudos de gestão patrimonial, pouco explorada no meio acadêmico e profissional da gestão pública brasileira.

\section{REFERÊNCIAS}

Bernardes, J. F. (2008). Gestão Patrimonial: materiais permanentes e bens móveis. Florianópolis: IU/UFSCS.

Bernardes, J. F. (2011). Administração Patrimonial. Florianópolis: IU/UFSCS, 2011.

Brasil. Constituição (1988). Constituição da República Federativa do Brasil. Brasília, DF: Senado 1988.

Brasil. Decreto n 3.591 de 06 de setembro de 2000 (2000). Dispóe sobre o Sistema de Controle Interno do Poder Executivo Federal e dá outras providências. Diário Oficial [da] República Federativa. Brasília, DF, 08 set. 2000. Disponível em: . Acesso em: 12 fev. 2018.

Brasil. Decreto-Lei no 200 de 25 de fevereiro de 1967 (1967). Dispõe sobre a organização da Administração Federal, estabelece diretrizes para a Reforma Administrativa e dá outras providências. Diário Oficial [da] República Federativa. Brasília, DF, 27 fev. 1967. Disponível em: < http://www.planalto.gov.br/ccivil_03/decreto-lei/ del0200.htm >. Acesso em: 02 mai. 2015.

Brasil. Lei 4.320, de 17 de março de 1964 (1964). Estatui Normas Gerais de Direito Financeiro para elaboração e controle dos orçamentos e balanços da União, dos Estados, dos Municípios e do Distrito Federal. Diário Oficial [da] República Federativa. Brasília, DF, 23 mar. 1964. Disponível em: . Acesso em: 02 jun. 2015.

Brasil. Lei 8.666, de 21 de junho de 1993 (1993). Regulamenta o art. 37, inciso XXI, da Constituição Federal, institui normas para licitações e contratos da Administração Pública e dá outras providências. Diário Oficial [da] República Federativa. Brasília, DF, 22 mar. 1993. Disponível em: . Acesso em: 02 jun. 2015.

Brasil. Lei 10.180, de 06 de fevereiro de 2001 (2001). Organiza e disciplina os Sistemas de Planejamento e de Orçamento Federal, de Administração Financeira Federal, de Contabilidade Federal e de Controle Interno do Poder Executivo Federal, e dá outras providências. Diário Oficial [da] República Federativa. Brasília, DF, 07 fev. 2001. Disponível em: < http://www.planalto.gov.br/ccivil_03/LEIS/LEIS_2001/L10180.htm>. Acesso em: 12 fev. 2018.

Brasil. Ministério da Fazenda. Secretaria do Tesouro Nacional. Manual de Contabilidade Aplicada ao Setor Público. 7. ed. (2017) Disponível em: < http://www.tesouro.fazenda.gov.br/documents/10180/456785/ MCASP+7\%C2\%AA\%20edi\% C3\%A7\%C3\%A3o+Vers\%C3\%A3o+Final.pdf/6e874adb-44d7-490c-8967b0acd3923f6d $>$. Acesso em: 18 nov. 2017.

Brasil. Ministério da Fazenda. Tesouro Nacional. Manual do Sistema Integrado De Administração Financeira Do Governo Federal - SIAFI. Brasília (2017b). Disponível em: . Acesso em: 18 nov. 2017.

Brasil. Ministério da Fazenda. Secretaria do Tesouro Nacional. Manual SIAFI Web - Macro função 02.03 .30 Depreciação, Amortização, Exaustão na Administração Direta da União, Autarquias e Fundações (2017). Esta Macrofunção disponibilizamos os procedimentos para os registros da depreciação, amortização e exaustão dos bens para a Administração direta da União, suas autarquias e fundações. Brasília. Disponível em: . Acesso em: 10 jan. 2018

Brasil. Secretaria de Administração Pública da Presidência da República - SEDAP/PR. Instrução Normativa no 205, de 08 de abril 1988. (1988). Diário Oficial [da] República Federativa. Brasília, DF, 11 abr. 1988. Disponível em: . Acesso em: 30 abr. 2016.

Cardozo, B. D. A.; Araújo, G. C.; Silva, C. R.; Silva, M. A. C. (2013). Comprometimento Organizacional e gestão de Bens materiais e Patrimoniais: um estudo de caso em uma cooperativa de reciclagem. In: Encontro de Gestão de Pessoas e Relações de Trabalho - EnGPR, 4., 2013, Brasília. Anais... Brasília: ANPAD, p. 1-16.

Cervo, A. L.; Bervian, P. A.; Da Silva, R. (2007). Metodologia Científica. 6. ed. São Paulo: Pearson Prentice Hall.

Coutinho, J. R. A. (2004). Gestão Patrimonial na Administração Pública: noções gerais sobre os bens das entidades que integram a administração pública e sua utilização. Rio de Janeiro: Lumen Juris.

Fenili, R. R. (2015). Gestão de Materiais. Brasília: ENAP. 
Figueredo, F. C. M. (2015). Gestão Patrimonial: um estudo sobre o controle de material permanente na Universidade Federal do Maranhão. $93 \mathrm{f}$.

If Sertão-Pe. Instituto Federal de Educação, Ciência e Tecnologia do Sertão Pernambucano. Resolução $\mathrm{n}^{\circ} 18$ do Conselho Superior, de 14 de junho de 2017 (2017). Disponível em: https://www.ifsertao-pe.edu.br/images/IF_Sertao-PE/Documentos/Conselho-Superior/ Resolucoes/2017/Resoluo\%20n\%2018\%20INSTRUO\%20NORMATIVA\%20N\%20x1\%20final.pdf. Acesso em: 11 jul. 2017.

If Sertão-Pe. Instituto Federal de Educação, Ciência e Tecnologia do Sertão Pernambucano. Relatório de Gestão do Exercício de 2012 (2013). Disponível: https://www.ifsertao-pe.edu.br/images/IF_Sertao-PE/Documentos/ Auditorias/Exerccio\%20de\%202012.pdf>. Acesso: 11 jul. 2017.

If Sertão-Pe. Instituto Federal de Educação, Ciência e Tecnologia do Sertão Pernambucano. Relatório de Gestão do Exercício de 2013. (2014b). Disponível: < https://www.ifsertao-pe.edu.br/images/IF_Sertao-PE/ Documentos/Auditorias/Exerccio\%20de\%202013.pdf>. Acesso: 11 jul. 2017.

Martins, P. V. Administração e Controle Patrimonial. Curso: Administração e Controle Patrimonial (2012). Disponível em: . Acesso em 01 maio. 2016.

Martins, M. M. E.; Sousa, G. G.; Nascimento, V. A.; Rocha, D. T. M. (2013). Novo modelo de gestão patrimonial do estado de Pernambuco: o controle dos bens públicos à luz das novas normas brasileiras de contabilidade (NBCASP). In: Congresso CONSAD (Conselho Nacional de Secretários do Estado da Administração) de Gestão Pública, 6., 4., 2013, Brasília. Anais... Brasília: CONSAD. p. 1-26.

Nascimento, S. G. V. (2013) A gestão patrimonial de bens móveis de caráter permanente na UFPB e na UFRN. 2013. 152f. Dissertação (Mestrado Profissional em Gestão de Organizações Aprendentes) - Centro de Educação, Centro de Ciências Sociais e Aplicadas, Universidade Federal da Paraíba, João Pessoa.

Pozo, H. (2007) Administração de recursos materiais e patrimoniais: uma abordagem logística. 4. ed. São Paulo: Atlas.

Quintana, A. C.; Machado, D. P.; Quaresma, J. C. C.; Mendes, R. C. (2011). Contabilidade Pública: De acordo com as novas Normas Brasileiras de Contabilidade aplicadas ao setor público e a Lei de Responsabilidade Fiscal. São Paulo: Atlas.

Santos, G. (2002). Manual de Administração Patrimonial. Florianópolis.

Santos, G. (2016). Gestão Patrimonial: Ampliada e atualizada. 5.ed. Florianópolis: Secco.

\section{BY-NC-ND}

